Producing Desire 
STUDIES ON THE HISTORY OF SOCIETY AND CULTURE

Victoria E. Bonnell and Lynn Hunt, Editors 


\section{Producing Desire}

Changing Sexual Discourse in the

Ottoman Middle East, I 500-I900

Dror Ze'evi

무

UNIVERSITY OF CALIFORNIA PRESS

Berkeley • Los Angeles . London 
University of California Press, one of the most distinguished university presses in the United States, enriches lives around the world by advancing scholarship in the humanities, social sciences, and natural sciences. Its activities are supported by the UC Press Foundation and by philanthropic contributions from individuals and institutions. For more information, visit www.ucpress.edu.

University of California Press Berkeley and Los Angeles, California

University of California Press, Ltd. London, England

C 2006 by The Regents of the University of California

Library of Congress Cataloging-in-Publication Data

\section{Ze'evi, Dror, I953-}

Producing desire : changing sexual discourse in the Ottoman Middle East, I 500-I900 / Dror Ze'evi. p. $\mathrm{cm}$.-(Studies on the history of society and culture)

Includes bibliographical references and index. ISBN I 3: 978-0-520-24564-8 (cloth : alk. paper), ISBN IO: 0-520-24564-4 (cloth : alk. paper) ISBN I 3: 978-0-520-24563-I (pbk. : alk. paper), ISBN IO: 0-520-24563-6 (pbk. : alk. paper)

I. Sex customs-Middle East. 2. Desire.

I. Title. II. Series.

HQI 8.M52Z44 2006

306.7'0956'0903-dc22 2005013949

Manufactured in the United States of America

$\begin{array}{llllllllll}\text { I } 5 & \text { I } 4 & \text { I3 } & \text { I2 } & \text { II } & \text { IO } & 09 & 08 & 07 & 06\end{array}$

$\begin{array}{llllllllll}\text { IO } & 9 & 8 & 7 & 6 & 5 & 4 & 3 & 2 & \text { I }\end{array}$

This book is printed on New Leaf EcoBook 50, a I00\% recycled fiber of which $50 \%$ is de-inked postconsumer waste, processed chlorine-free. EcoBook 50 is acid-free and meets the minimum requirements of ANSI/ASTM D 5634-OI (Permanence of Paper).@ 
In memory of my father,

Benny,

a man of integrity and love 
